\title{
Rickettsial infection in equids, opossums and ticks in the municipality of Monte Mor, state of São Paulo, Brazil
}

\author{
Infecção por Rickettsia spp. em equídeos, gambás e carrapatos do município \\ de Monte Mor, estado de São Paulo, Brasil
}

Tatiana Evelyn Hayama Ueno1* (D); André Antonio Cutolo²; Thiago Fernandes Martins³; Jonas Moraes-Filho4; Sérgio Santos de Azevedo; ${ }^{5}$ Marcelo Bahia Labruna ${ }^{3}$

\author{
'Polo Regional Alta Sorocabana, Agência Paulista de Tecnologia dos Agronegócios - APTA, Presidente Prudente, SP, Brasil \\ ${ }^{2}$ Faculdade de Medicina Veterinária e Zootecnia, Universidade Estadual Paulista - UNESP, Botucatu, SP, Brasil \\ ${ }^{3}$ Faculdade de Medicina Veterinária e Zootecnia, Universidade de São Paulo - USP, São Paulo, SP, Brasil \\ ${ }^{4}$ Universidade Santo Amaro, São Paulo, SP, Brasil \\ ${ }^{5}$ Centro de Saúde e Tecnologia Rural, Universidade Federal de Campina Grande - UFCG, Patos, PB, Brasil
}

How to cite: Ueno TEH, Cutolo AA, Martins TF, Moraes-Filho J, Azevedo SS, Labruna MB. Rickettsial infection in equids, opossums and ticks in the municipality of Monte Mor, state of São Paulo, Brazil. Braz J Vet Parasitol 2020; 29(4): e015420. https://doi. org/10.1590/S1984-29612020073

\begin{abstract}
The aim of this study was to investigate rickettsial infection in equids, opossums and ticks in the municipality of Monte Mor, a place where a Brazilian spotted fever case occurred in 2005. In addition, characteristics possibly associated with seropositivity in horses were analyzed. Serum samples from horses, mules and opossums (Didelphis albiventris) were subjected to indirect immunofluorescence assay (IFA) against Rickettsia rickettsii. The ticks collected from the animals were identified and Amblyomma sculptum ticks from the equids were tested using PCR for Rickettsia spp. Anti-R. rickettsii antibodies were detected in $22.6 \%$ (14/62) of the horses, none of the mules and $21.7 \%$ (5/23) of the opossums. Among the variables analyzed, only age $>12$ years showed a statistically significant association with seropositivity among horses. All of the 166 A. sculptum ticks tested using PCR were negative. The results showed that rickettsiae of the spotted fever group was circulating in the municipality of Monte Mor when the samples were collected and indicate a need for surveillance of Brazilian spotted fever in this region.
\end{abstract}

Keywords: Rickettsiales, spotted fever, equine, Didelphis, São Paulo.

\section{Resumo}

Este trabalho objetivou pesquisar a infecção por Rickettsia spp. em equídeos, gambás e carrapatos, do município de Monte Mor, local que teve um caso de febre maculosa brasileira, em 2005. Além disso, características possivelmente associadas com a soropositividade nos equinos foram analisadas. Soros de equinos, muares e gambás Didelphis albiventris foram submetidos à reação de imunofluorescência indireta (RIFI) contra Rickettsia rickettsii. Os carrapatos coletados dos animais foram identificados e os carrapatos Amblyomma sculptum dos equídeos foram testados pela PCR para Rickettsia spp. Anticorpos anti-R. rickettsii foram detectados em $22,6 \%$ (14/62) equinos, zero muares e 21,7\% (5/23) gambás. Entre as variáveis analisadas, apenas a idade maior que 12 anos mostrou associação estatisticamente significante com a soropositividade em equinos. De 166 carrapatos $A$. sculptum testados pela PCR, todos foram negativos. Os resultados mostram que riquétsias do grupo da febre maculosa estavam circulando no município de Monte Mor, quando as amostras foram coletadas, e apontam para a necessidade de vigilância para a febre maculosa brasileira nessa região.

Palavras-chave: Rickettsiales, febre maculosa, equinos, Didelphis, São Paulo. 


\section{Introduction}

The genus Rickettsia consists of multiple species of obligate intracellular bacteria. Some of them are pathogenic to humans and animals, while others are not pathogenic or have unknown pathogenicity (Weinert et al., 2009). These bacteria have been divided into groups according to their serological or molecular profile (Raoult \& Roux, 1997; Weinert et al., 2009). The spotted fever group (SFG) contains one of the most pathogenic rickettsiae in the world, Rickettsia rickettsii, which causes Brazilian spotted fever (BSF) in Brazil (Parola et al., 2013). In this country, the vectors for $R$. rickettsii are the ticks Amblyomma sculptum and Amblyomma aureolatum (Szabó et al., 2013).

Specifically, in the region of Brazil where the municipality of Monte Mor is located, the vector is the tick A. sculptum (Szabó et al., 2013). Horses and opossums are good sentinels for $R$. rickettsii in areas where the vector is $A$. sculptum, since these animals are hosts for this tick and, when they come into contact with $R$. rickettsii, they produce antibodies at high level in large quantities that continue to be present for at least six months in opossums or at least two years in horses (Horta et al., 2009; Ueno et al., 2016). Opossums are also amplifier hosts of R. rickettsii for A. sculptum ticks, because they present rickettsemia and can be source of infection to ticks (Horta et al., 2009). Horses, in opposite, cannot transmit the bacterium to the tick vector (Ueno et al., 2016). There are no studies that assessed the susceptibility of mules to $R$. rickettsii and their role as amplifying hosts.

The municipality of Monte Mor belongs to the microregion of Campinas, in the state of São Paulo (Figure 1), in southeastern Brazil, which encompasses 16 municipalities. To date, only one case of BSF (which occurred in 2005) has ever been confirmed in this municipality (Brasil, 2019). However, over the whole microregion of Campinas, 379 BSF cases were confirmed from 2001 to 2017 (Brasil, 2019). This region has the highest number of notifications of the disease in Brazil.

Monte Mor is characterized by urban pockets that have been formed along the SP-101 highway. Among these urban areas and around them there are rural properties and regions of environmental preservation that have been anthropized and occupied irregularly (Cutolo et al., 2014). The city is crossed by several watercourses, the main

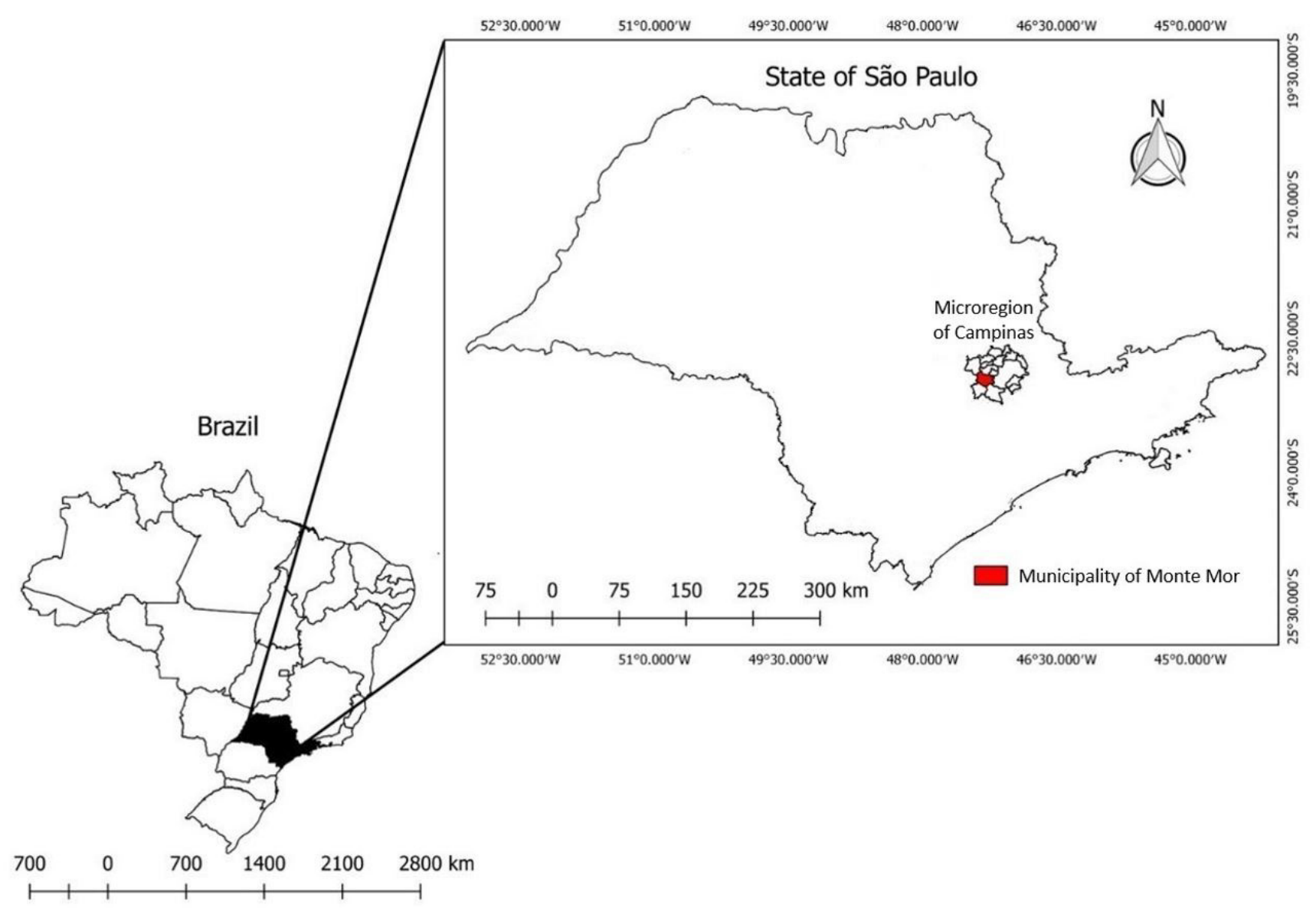

Figure 1. Location of the municipality of Monte Mor, in the state of São Paulo, Brazil. 
one being the Capivari River, which belongs to the Tietê River basin. The municipality has few forest fragments, consisting mainly of riparian forest around the rivers and secondary forests scattered throughout the rural area. Part of the rivers and riparian forests are in the urban area of the city (Instituto Florestal, 2009).

The aims of this study were to investigate antibodies against $R$. rickettsii in horses, mules and opossums in the municipality of Monte Mor, to identify characteristics associated with seropositivity among horses and to investigate rickettsial DNA in A. sculptum ticks found in these animals.

\section{Material and Methods}

\section{Sample collection}

From January to July 2011, as part of an equid health program in the municipality of Monte Mor, a convenience sample of horses and mules from the urban and periurban region of the municipality was subjected to blood collection via jugular vein puncture and tick collection (Cutolo et al., 2014).

From December 2009 to November 2011, opossums (D. albiventris) were caught manually or using nets in urban or periurban residential areas of the municipality of Monte Mor, after the residents had notified the municipality's Zoonosis Control Department regarding the presence of these animals. From June 2011 to May 2012, other opossums were caught by means of Tomahawk traps in the rural area of Monte Mor as part of a study on opossum parasites (Teodoro et al., 2019). The sampling was also by convenience. The opossums thus caught were then subjected to blood collection by means of puncture of the ventral caudal vein and collection of ticks.

\section{Indirect immunofluorescence assay}

The equid and opossum blood samples were subsequently centrifuged at $3000 \mathrm{~g}$ for ten minutes to separate the serum, which was stored in microtubes at $-20^{\circ} \mathrm{C}$ until processing. In order to test for the presence of IgG antibodies against rickettsiae of the SFG, the serum samples were subjected to indirect immunofluorescence assay (IFA), as previously described (Horta et al., 2004), using the Taiaçu strain of $R$. rickettsii as the crude antigen. The secondary antibodies used were anti-horse IgG conjugate (Sigma, St Louis, MO, USA) and anti-opossum IgG conjugate (produced by the Zoonosis Control Center of São Paulo, Brazil). The serum samples were first tested at the dilution 1:64, and those that showed a positive result were retested at twofold serial dilutions, to determine the endpoint titers. On each slide, positive and negative control serum samples from horses (derived from the work of Ueno et al., 2016) or opossums (derived from the work of Horta et al., 2009) were processed simultaneously with the samples.

\section{Statistical analysis}

At the time of sample collection, some information about the horses was obtained from the current owner. This included the animals' sex and age, the neighborhood in which they lived, the activity for which they were used and the length of ownership. These data were input to bivariate analysis by using chi-squared test, G test or Fisher's exact test and calculating prevalence ratio and respective binomial confidence interval of 95\% (Martinez et al., 2017) to identify variables associated with seropositivity. Differences were considered significant when $p<0.05$. The analyses were performed on R environment (R Core Team, 2019) with the package "epiR" (Stevenson, 2020).

\section{Tick identification}

The ticks collected from the equids and opossums were stored in Falcon plastic tubes containing $70 \%$ ethanol, until processing. The adult ticks of Rhipicephalus microplus, all the stages of Dermacentor nitens and larvae of Amblyomma spp. were identified in accordance with Barros-Battesti et al. (2006). The adults of A. sculptum were identified according to Nava et al. (2014). Nymphs of the genera Amblyomma were identified according to Martins et al. (2010). The mean abundance and mean intensity were calculated according to Bush et al. (1997).

\section{Molecular analysis}

The ticks from equids that were identified as A. sculptum, a recognized vector for BSF, were subjected to DNA extraction using guanidine isothiocyanate-phenol solution, as previously described (Sangioni et al., 2005). Then, the samples were tested for the presence of Rickettsia spp. DNA by means of PCR targeting the gltA gene, using the 
primers CS78 and CS323 (Labruna et al., 2004). Each reaction was prepared to a final volume of $25 \mu \mathrm{L}$, containing $1 \times$ buffer, $2 \mathrm{mM}$ of $\mathrm{MgCl}_{2}, 0.25 \mathrm{mM}$ of each dNTP, $0.6 \mu \mathrm{M}$ of each primer, $1.5 \mathrm{U}$ of DNA polymerase, $10.85 \mu \mathrm{L}$ of ultrapure water and $2.5 \mu \mathrm{L}$ of DNA. The reactions were carried out under the following conditions: initial denaturation at $95^{\circ} \mathrm{C}$ for $3 \mathrm{~min}$, then $40 \mathrm{cycles}$ of $95^{\circ} \mathrm{C}$ for $15 \mathrm{~s}, 48^{\circ} \mathrm{C}$ for $30 \mathrm{~s}$ and $72{ }^{\circ} \mathrm{C}$ for $30 \mathrm{~s}$, with final extension at $72^{\circ} \mathrm{C}$ for $7 \mathrm{~min}$. The other ticks recovered from equids that are not recognized as vectors for BSF were not tested. The ticks recovered from opossums were deposited in the tick collection "Coleção Nacional de Carrapatos Danilo Gonçalves Saraiva" (CNC) of the FMVZ-USP, so they were not tested for rickettsial DNA.

\section{Institutional permissions}

This study was approved by the Ethics Committee for Animal Use of the State University of Campinas (CEUA/UNICAMP) (protocol number 2546-1). Authorization to handle wild opossums was obtained from the Brazilian Institute for the Environment and Renewable Natural Resources (IBAMA) (protocol number 31724 -1).

\section{Results}

Serum samples were obtained from 62 horses and three mules in ten neighborhoods of the municipality of Monte Mor. In addition, serum samples from 23 D. albiventris opossums were obtained (17 opossums were caught in urban and periurban areas after notification from residents and six were caught by means of traps in rural areas).

Among the 62 samples from horses that were tested using IFA, 14 (22.6\%) were positive for $R$. rickettsii (Table 1). The titers ranged from 64 to 2048. No mule samples were positive in IFA. Among the opossum samples, 5/23 (21.7\%) were positive for $R$. rickettsii (Table 1), with titers ranging from 64 to 256.

The bivariate analysis on the characteristics of the horses (sex, age, neighborhood, use and length of ownership) showed that only age $>12$ years was associated with seropositivity for $R$. rickettsii (prevalence ratio $=3.13$; $p=0.010$ ), as shown in Table 2 . Horses aged $>12$ years presented 2.13 more chances to be seropositive than horses $\leq 12$ years old.

Among the 62 horses examined for the presence of ticks, 46 were infested. The mean abundance of ticks was 6.9 and the mean intensity was 9.2. Out of a total of 425 ticks that were collected, $59.8 \%$ (254/425) were identified as D. nitens, 38.6\% (164/425) as A. sculptum and 1.6\% (7/425) as R. microplus (Table 3).

Among the three mules that were examined, only one was parasitized. The mean abundance of ticks was 0.7 and the mean intensity was 2.0. Two adult $A$. sculptum ticks were removed from this animal.

Twenty-three opossums were examined and six were found to be parasitized by ticks. In these animals, the mean abundance of ticks was 2.0 and the mean intensity was 7.8. A total of 47 ticks were recovered, among which $44.7 \%$ (21/47) were $A$. sculptum nymphs, 38.3\% (18/47) were A. dubitatum nymphs and 17.0\% (8/47) were larvae of the genus Amblyomma (Table 3).

All the 166 A. sculptum ticks (98 males, 67 females and 1 nymph) that were found on the horses and mules were subjected to PCR for the gltA gene of Rickettsia spp. and were shown to be negative.

Table 1. Antibodies against Rickettsia rickettsii in horses, mules and opossums (Didelphis albiventris) in the municipality of Monte Mor, SP, which were tested by means of the indirect immunofluorescence assay (IFA $\geq 64$ ).

\begin{tabular}{|c|c|c|c|c|c|c|c|}
\hline \multirow{2}{*}{ Animal } & \multicolumn{6}{|c|}{$\begin{array}{l}\text { Titers } \\
\text { no. of positive samples according to the titer/total no. of positive samples }\end{array}$} & \multirow{2}{*}{$\begin{array}{c}\text { Total } \\
\text { (no. of positive } \\
\text { samples/no. of } \\
\text { samples tested) }\end{array}$} \\
\hline & 64 & 128 & 256 & 512 & 1024 & 2048 & \\
\hline Horses & 2/14 (14.3\%) & 2/14 (14.3\%) & $4 / 14(28.6 \%)$ & $3 / 14$ (21.4\%) & $2 / 14(14.3 \%)$ & $1 / 14(7.1 \%)$ & $14 / 62(22.6 \%)$ \\
\hline Mules & 0 & 0 & 0 & 0 & 0 & 0 & $0 / 3$ \\
\hline $\begin{array}{l}\text { Opossums } \\
\text { (D. albiventris) }\end{array}$ & $1 / 5(20 \%)$ & $1 / 5(20 \%)$ & $3 / 5(60 \%)$ & & & & $5 / 23(21.7 \%)$ \\
\hline
\end{tabular}


Table 2. Bivariate analysis performed to investigate associations between the characteristics of the horses and the presence of antibodies against $R$. rickettsii.

\begin{tabular}{|c|c|c|c|c|c|}
\hline Variables & Categories & Total no. of horses & No. of seropositive horses (\%) & Prevalence ratio $(95 \% \mathrm{CI})^{a}$ & $p$-value ${ }^{b}$ \\
\hline \multirow[t]{2}{*}{ Age } & Up to 12 years & 47 & $7(14.9)$ & Reference & \\
\hline & $>12$ years & 15 & $7(46.7)$ & $3.13(1.31-7.49)$ & 0.010 \\
\hline \multirow{2}{*}{$\begin{array}{l}\text { Length of } \\
\text { possession by the } \\
\text { current owner }\end{array}$} & Up to 5 years & 48 & $11(22.9)$ & Reference & \\
\hline & $>5$ years & 9 & $2(22.2)$ & $1.03(0.27-3.89$ & 0.349 \\
\hline \multirow[t]{2}{*}{ Sex } & Female & 30 & $6(20)$ & Reference & \\
\hline & Male & 32 & $8(25)$ & $1.25(0.49-3.18)$ & 0.639 \\
\hline \multirow[t]{6}{*}{ Neighborhood } & Panorama & 11 & $1(9.1)$ & Reference & \multirow{6}{*}{0.760} \\
\hline & Moreira & 5 & $1(20)$ & $2.20(0.17-28.53)$ & \\
\hline & Nova Alvorada & 10 & $2(20)$ & $2.20(0.23-20.72)$ & \\
\hline & Paviotti & 20 & $6(30)$ & $3.30(0.45-24.02)$ & \\
\hline & São Rafael & 9 & $3(33.3)$ & $3.67(0.46-29.49)$ & \\
\hline & Others* & 7 & $1(14.3)$ & $1.57(0.12-21.26)$ & \\
\hline \multirow[t]{3}{*}{ Use } & Foal not yet used & 7 & $0(0)$ & Reference & \multirow{3}{*}{0.164} \\
\hline & $\mathrm{Cart}^{+}$ & 18 & $5(27.8)$ & $4.63(0.29-74.27)$ & \\
\hline & Leisure ${ }^{\#}$ & 37 & $9(24.3)$ & $4.00(0.26-61.93)$ & \\
\hline
\end{tabular}

"The neighborhoods Engenho, Fahrid Calil, Centro, Clube de Campo and Colina were put together in the "others" group because of the very small number of horses in each of them; ${ }^{+}$The cart category corresponds to the horses that pulled carts used mainly to collect recyclable material; \#The leisure category corresponds to the horses used to riding, to draw leisure carts or as pets; a Confidence interval of 95\% for prevalence ratio; bProbability that null hypothesis is true.

Table 3. Ticks that were identified from horses, mules and opossums (Didelphis albiventris) in the municipality of Monte Mor, SP.

\begin{tabular}{|c|c|c|c|c|c|c|}
\hline \multirow[b]{2}{*}{ Host } & \multirow[b]{2}{*}{ Tick stage } & \multicolumn{5}{|c|}{ Ticks identified } \\
\hline & & $\begin{array}{l}\text { Amblyomma } \\
\text { sculptum }\end{array}$ & $\begin{array}{c}\text { Amblyomma } \\
\text { dubitatum }\end{array}$ & $\begin{array}{c}\text { Amblyomma } \\
\text { spp. }\end{array}$ & $\begin{array}{l}\text { Rhipicephalus } \\
\text { microplus }\end{array}$ & $\begin{array}{c}\text { Dermacentor } \\
\text { nitens }\end{array}$ \\
\hline \multirow[t]{4}{*}{ Horses } & Adults & 163 & & & 7 & 185 \\
\hline & Nymphs & 1 & & & & 65 \\
\hline & Larvae & & & & & 4 \\
\hline & Total & $164 / 425$ (38.6\%) & & & $7 / 425(1.6 \%)$ & $254 / 425(59.8 \%)$ \\
\hline \multirow[t]{2}{*}{ Mules } & Adults & 2 & & & & \\
\hline & Total & $2 / 2(100 \%)$ & & & & \\
\hline \multirow[t]{3}{*}{ Opossums (D. albiventris) } & Nymphs & 21 & 18 & & & \\
\hline & Larvae & & & 8 & & \\
\hline & Total & $21 / 47(44.7 \%)$ & $18 / 47(38.3 \%)$ & $8 / 47(17.0 \%)$ & & \\
\hline
\end{tabular}




\section{Discussion}

The IFA test showed that $22.6 \%$ of the horses and $21.7 \%$ of the opossums were positive, which indicates that SFG rickettsiae was circulating in the municipality of Monte Mor at the time when samples were obtained. More recent research is needed to check whether SFG rickettsiae are still circulating in the city nowadays.

In this study, a strain of $R$. rickettsii was used as the antigen in IFA. However, since cross-reactions occur between different Rickettsia species of the SFG (Horta et al., 2004), it is not possible to determine the species of Rickettsia responsible for infections. In Brazil, at least seven SFG rickettsiae have been reported, namely $R$. rickettsii, $R$. parkeri, R. amblyommatis, R. rhipicephali, "Candidatus R. andeanae" (Parola et al., 2013), "Candidatus R. colombianensi" (Luz et al., 2018) and "Candidatus R. paranaensis" (Peckle et al., 2019).

Because the municipality of Monte Mor is located in a BSF-endemic region, it is possible that $R$. rickettsii was the bacterium that caused some of the infections. In other studies that were conducted previously in municipalities neighboring Monte Mor, the frequencies of horses seropositivity for $R$. rickettsii ranged from $40.8 \%$ to $90 \%$ (Horta et al., 2004, 2007; Souza et al., 2016), while among opossums the frequency was 78.6\% (Horta et al., 2007). In these studies, the probable infectious rickettsiae (as determined from differences of antibody titers against different Rickettsia antigens) were $R$. rickettsii, $R$. parkeri or $R$. bellii.

Caution should be taken when analyzing the data from the present survey. As the sampling of the animals was done by convenience, it is not possible to extrapolate the results to the entire population of horses, mules and opossums of the municipality of Monte Mor. For the same reason, comparisons among the percentages of seropositive animals found in this study with frequencies found in other surveys should be done carefully.

Horses can be used as indicators for circulation of $R$. rickettsii in regions where the vector is $A$. sculptum, because when they come into contact with the bacterium, they produce long-lasting antibodies (Ueno et al., 2016). Moreover, these are domestic animals that can easily be handled for blood collection. Even in regions where there have never been cases of BSF or where cases have not occurred for a long time, such as Monte Mor, which has only had one case (reported in 2005), serological tests on horses have great value for active surveillance of BSF (Souza et al., 2016). On the other hand, horses are not good sentinels in places where the vector is probably not $A$. sculptum (Cunha et al., 2014; Oliveira et al., 2019).

Opossums also produce antibodies that persist for a long time after infection by $R$. rickettsii, and these animals can also be used as indicators for circulation of this microorganism in a region (Horta et al., 2007, 2009). In addition, these animals may have a limited role as amplifier hosts of $R$. rickettsii for $A$. sculptum ticks, since they can infect a small amount of susceptible ticks in situations of rickettsemia (Horta et al., 2009).

In the present study, none of the three mules was seropositive to R. rickettsii. Other studies have found percentages of seropositive donkeys lower than percentages observed in horses. Horta et al. (2004) found 0/4 donkey seropositive to $R$. rickettsii in Pedreira, a municipality near Monte Mor, and Otomura et al. (2016) found 2/45 (4.4\%) seropositive donkeys in northeastern Paraná. Although there is no research that evaluated the role of the hybrid equid (Equus caballus $x$ Equus asinus) on the epidemiology of $R$. rickettsii, it is possible that this animal is not a good sentinel, since donkeys are more resistant to the tick vector A. sculptum than horses (Castagnolli et al., 2003) and the population of mules in the state of São Paulo is small (IBGE, 2017).

Among the variables analyzed to test possible associations with seropositivity for $R$. rickettsii among horses, only age presented a statistically significant association, with animals aged $>12$ years presenting 2.13 more chances to be seropositive. This can be explained by the fact that older animals have had greater opportunity to become infected over the course of their lifespan than younger animals. Silveira et al. (2015) observed that horses that had lived on the same farm for more than 8.5 years were more likely to be seropositive for SFG Rickettsia spp.

There was no association between the neighborhoods and the seropositivity of horses. This may have happened due to the small number of samples and the dispersion of horses between the neighborhoods. In addition, the neighborhoods where the horses rested may not be a useful variable in this study because most horses did not stay in these places all the time, but moved around the city (these animals were used to pull carts for transporting people and recyclable material, besides horse riding). Thus, it is not possible to determine where these horses acquired the infection. Another issue to be clarified is whether horses could carry infected ticks from one place to another. In the region of Campinas, where Monte Mor is located, human cases of BSF were associated with the presence of capybaras, watercourses, and the ticks A. sculptum and A. dubitatum, with tendency to urbanization of cases over time (Nasser, 2014). The only confirmed BSF case in Monte Mor occurred in the urban area of the 
city, close to the downtown (Nasser, 2014). Other studies are needed to assess where the risk areas are in the municipality of Monte Mor using georeferencing tools, and which environmental factors are associated with the presence of rickettsiae.

The three species of ticks that were recovered from equids in the present study ( $D$. nitens, $A$. sculptum and R. microplus) are species commonly found parasitizing equids in several regions of Brazil (Labruna et al., 2001; Dantas-Torres, 2009; Martins et al., 2009; Alves et al., 2014).

In the opossums, A. sculptum nymphs, A. dubitatum nymphs and Amblyomma spp. larvae were found. The ticks $A$. sculptum and $A$. dubitatum, mainly at immature stages, have been found in opossums of the species D. albiventris and D. aurita in the southeastern and central-western regions of Brazil (Horta et al., 2007; Perez et al., 2008; Saraiva et al., 2012; Silveira et al., 2015; Sponchiado et al., 2015). The main hosts for the tick A. sculptum are horses, capybaras and tapirs (Labruna et al., 2001), but it can also parasitize several other animals, including opossums (Estrada-Peña et al., 2004). The main host for all stages of $A$. dubitatum is capybaras, but it is common to find immature stages of this tick on opossums (Horta et al., 2007; Nava et al., 2010).

All the specimens of $A$. sculptum that were tested by means of PCR were negative. This is concordant with data from previous studies, which did not find any positive ticks or found only a very low rate of infected $A$. sculptum ticks, even among ticks collected in BSF-endemic regions (Guedes et al., 2005; Sangioni et al., 2005). This low prevalence of $R$. rickettsii infection in $A$. sculptum ticks can possibly be explained by these ticks' low capacity to acquire the infection (Labruna et al., 2008), decreased reproductive ability in infected ticks and a low rate of transovarian transmission (Soares et al., 2012; Costa et al., 2020). Thus, PCR on ticks may only have minimal usefulness for detecting Rickettsia spp. circulation in any given region, compared with serological tests.

\section{Conclusions}

We concluded that SFG rickettsiae was present and circulating in the municipality of Monte Mor when the samples were collected. This emphasizes the importance of BSF surveillance in this municipality, even though only one case has been registered so far.

\section{Acknowledgements}

This study was financed in part by the Coordenação de Aperfeiçoamento de Pessoal de Nível Superior - Brasil (CAPES) - Finance Code 001. We thank the personnel of the Zoonoses Control Department of the municipality of Monte Mor, especially Paulo Milani and Anna Karollina Menezes Teodoro, for all their support in handling and restraining the animals that were included in this study.

\section{References}

Alves AS, Melo ALT, Amorim MV, Borges AMCM, Silva LG, Martins TF, et al. Seroprevalence of Rickettsia spp. in equids and molecular detection of "Candidatus Rickettsia amblyommii" in Amblyomma cajennense sensu lato ticks from the Pantanal region of Mato Grosso, Brazil. J Med Entomol 2014; 51(6): 1242-1247. http://dx.doi.org/10.1603/ME14042. PMid:26309313.

Barros-Battesti DM, Arzua M, Bechara GH. Carrapatos de importância médico-veterinária da Região Neotropical: um guia ilustrado para identificação de espécies. São Paulo: Vox/International Consortium on Ticks and Tick-borne Diseases (ICTTD-3)/Butantan; 2006.

Brasil. Ministério da Saúde. Sistema de Informação de Agravos de Notificação. Casos confirmados notificados no Sistema de Informação de Agravos de Notificação - São Paulo [online]. 2019 [cited 2019 Jan 4]. Available from: http://tabnet.datasus.gov.br/ cgi/deftohtm.exe?sinannet/cnv/febremaculosasp.def

Bush AO, Lafferty KD, Lotz JM, Shostak AW. Parasitology meets ecology on its own terms: Margolis et al. revisited. J Parasitol 1997; 83(4): 575-583. http://dx.doi.org/10.2307/3284227. PMid:9267395.

Castagnolli KC, Figueiredo LB, Santana DA, Castro MB, Romano MA, Szabó MP. Acquired resistance of horses to Amblyomma cajennense (Fabricius, 1787) ticks. Vet Parasitol 2003; 117(4): 271-283. http://dx.doi.org/10.1016/j.vetpar.2003.09.004. PMid:14637029.

Costa FB, Gerardi M, Binder LC, Benatti HR, Serpa MC, Lopes B, et al. Rickettsia rickettsii (Rickettsiales: Rickettsiaceae) infecting Amblyomma sculptum (Acari: Ixodidae) ticks and capybaras in a Brazilian spotted fever-endemic area of Brazil. J Med Entomol 2020; 57(1): 308-311. http://dx.doi.org/10.1093/jme/tjz141. PMid:31504641. 
Cunha NC, Lemos ERS, Rozental T, Teixeira RC, Cordeiro MD, Lisbôa RS, et al. Rickettsiae of the Spotted Fever group in dogs, horses and ticks: an epidemiological study in an endemic region of the State of Rio de Janeiro, Brazil. Rev Bras Med Vet 2014; 36(2): 294-300.

Cutolo AA, Gonçalves VLN, Correzola LM, Gunnewiek MFK. Anemia infecciosa equina em equídeos de área urbana do município de Monte Mor, região metropolitana de Campinas, Estado de São Paulo, Brasil. Semina: Ciênc Agrár 2014; 35(3): 1377-1382. http:// dx.doi.org/10.5433/1679-0359.2014v35n3p1377.

Dantas-Torres F. Ticks on domestic animals in Pernambuco, Northeastern Brazil. Rev Bras Parasitol Vet 2009; 18(3): 22-28. http:// dx.doi.org/10.4322/rbpv.01803004. PMid:19772771.

Estrada-Peña A, Guglielmone AA, Mangold AJ. The distribution and ecological 'preferences' of the tick Amblyomma cajennense (Acari: Ixodidae), an ectoparasite of humans and other mammals in the Americas. Ann Trop Med Parasito/ 2004; 98(3): $283-292$. http://dx.doi.org/10.1179/000349804225003316. PMid:15119974.

Guedes E, Leite RC, Prata MC, Pacheco RC, Walker DH, Labruna MB. Detection of Rickettsia rickettsii in the tick Amblyomma cajennense in a new Brazilian spotted fever endemic area in the state of Minas Gerais. Mem Inst Oswaldo Cruz 2005; 100(8): 841845. http://dx.doi.org/10.1590/S0074-02762005000800004. PMid:16444414.

Horta MC, Labruna MB, Pinter A, Linardi PM, Schumaker TT. Rickettsia infection in five areas of the state of São Paulo, Brazil. Mem Inst Oswaldo Cruz 2007; 102(7): 793-801. http://dx.doi.org/10.1590/S0074-02762007000700003. PMid:18094887.

Horta MC, Moraes J Fo, Casagrande RA, Saito TB, Rosa SC, Ogrzewalska M, et al. Experimental infection of opossums Didelphis aurita by Rickettsia rickettsii and evaluation of the transmission of the infection to ticks Amblyomma cajennense. Vector Borne Zoonotic Dis 2009; 9(1): 109-118. http://dx.doi.org/10.1089/vbz.2008.0114. PMid:18945194.

Horta MC, Vianna MCB, Mafra CL, Schumaker TTS, Walker DH, Galvão MAM, et al. Prevalence of antibodies to spotted fever group rickettsiae in humans and domestic animals in a Brazilian spotted fever-endemic area in the state of São Paulo, Brazil: serologic evidence for infection by Rickettsia rickettsii and another spotted fever group Rickettsia. Am J Trop Med Hyg 2004; 71(1): 93-97. http://dx.doi.org/10.4269/ajtmh.2004.71.93. PMid:15238696.

Instituto Brasileiro de Geografia e Estatística - IBGE. Censo agropecuário 2017: número de cabeças de muares nos estabelecimentos agropecuários [online]. 2017 [cited 2020 June 16]. Available from: https://sidra.ibge.gov.br/pesquisa/censo-agropecuario/censoagropecuario-2017\#pecuaria

Instituto Florestal. Sistema de Informações Florestais do Estado de São Paulo. Inventário florestal do estado de São Paulo [online]. 2009 [cited 2020 June 16]. Available from: https://www.infraestruturameioambiente.sp.gov.br/sifesp/mapas-municipais/

Labruna MB, Kerber CE, Ferreira F, Faccini JLH, de Waal DT, Gennari SM. Risk factors to tick infestations and their occurrence on horses in the state of São Paulo, Brazil. Vet Parasitol 2001; 97(1): 1-14. http://dx.doi.org/10.1016/S0304-4017(01)00387-9. PMid:11337122.

Labruna MB, Ogrzewalska M, Martins TF, Pinter A, Horta MC. Comparative susceptibility of larval stages of Amblyomma aureolatum, Amblyomma cajennense, and Rhipicephalus sanguineus to infection by Rickettsia rickettsii. J Med Entomol 2008; 45(6): 1156-1159. http://dx.doi.org/10.1603/0022-2585(2008)45[1156:CSOLSO]2.0.CO;2. PMid:19058642.

Labruna MB, Whitworth T, Horta MC, Bouyer DH, McBride JW, Pinter A, et al. Rickettsia species infecting Amblyomma cooperi ticks from an area in the state of São Paulo, Brazil, where Brazilian spotted fever is endemic. J Clin Microbio/ 2004; 42(1): 90-98. http:// dx.doi.org/10.1128/JCM.42.1.90-98.2004. PMid:14715737.

Luz HR, Silva-Santos E, Costa-Campos CE, Acosta I, Martins TF, Muñoz-Leal S, et al. Detection of Rickettsia spp. in ticks parasitizing toads (Rhinella marina) in the northern Brazilian Amazon. Exp App/ Acarol 2018; 75(3): 309-318. http://dx.doi.org/10.1007/s10493018-0270-y. PMid:29846852.

Martinez BAF, Leotti VB, Silva GS, Nunes LN, Machado G, Corbellini LG. Odds ratio or prevalence ratio? An overview of reported statistical methods and appropriateness of interpretations in cross-sectional studies with dichotomous outcomes in Veterinary Medicine. Front Vet Sci 2017; 4: 193. http://dx.doi.org/10.3389/fvets.2017.00193. PMid:29177157.

Martins TF, Onofrio VC, Barros-Battesti DM, Labruna MB. Nymphs of the genus Amblyomma (Acari: Ixodidae) of Brazil: descriptions, redescriptions, and identification key. Ticks Tick Borne Dis 2010; 1(2): 75-99. http://dx.doi.org/10.1016/j.ttbdis.2010.03.002. PMid:21771514.

Martins TF, Spolidorio MG, Batista TCA, Oliveira IAS, Yoshinari NH, Labruna MB. Ocorrência de carrapatos (Acari: Ixodidae) no município de Goiatins, Tocantins. Rev Bras Parasitol Vet 2009; 18(2): 50-52. http://dx.doi.org/10.4322/rbpv.01802011. PMid:19602318.

Nasser JT. A febre maculosa brasileira na Região Metropolitana de Campinas/SP: sua distribuição espacial e os desafios das ações de prevenção e controle locais [tese]. Campinas: Universidade Estadual de Campinas; 2014. 
Nava S, Beati L, Labruna MB, Cáceres AG, Mangold AJ, Guglielmone AA. Reassessment of the taxonomic status of Amblyomma cajennense (Fabricius, 1787) with the description of three new species, Amblyomma tonelliae n. sp., Amblyomma interandinum n. sp. and Amblyomma patinoi n. sp., and reinstatement of Amblyomma mixtum Koch, 1844, and Amblyomma sculptum Berlese, 1888 (Ixodida: ixodidae). Ticks Tick Borne Dis 2014; 5(3): 252-276. http://dx.doi.org/10.1016/j.ttbdis.2013.11.004. PMid:24556273.

Nava S, Venzal JM, Labruna MB, Mastropaolo M, González EM, Mangold AJ, et al. Hosts, distribution and genetic divergence (16S rDNA) of Amblyomma dubitatum (Acari: ixodidae). Exp Appl Acarol 2010; 51(4): 335-351. http://dx.doi.org/10.1007/s10493-0099331-6. PMid:20084537.

Oliveira AS, Carvalho TRV, Labruna MB, Moraes-FilhoJ. Brazilian spotted fever serological survey among equids at the Guarapiranga Dam area in the city of São Paulo, Brazil. Braz J Vet Res Anim Sci 2019; 56(4): e158601. http://dx.doi.org/10.11606/issn.1678-4456. bjvras.2019.158601.

Otomura FH, Truppel JH, Moraes J, Labruna MB, Rossoni DF, Massafera R, et al. Probability of occurrence of the Brazilian spotted fever in northeast of Paraná state, Brazil. Rev Bras Parasitol Vet 2016; 25(4): 394-400. http://dx.doi.org/10.1590/s198429612016060. PMid:27925056.

Parola P, Paddock CD, Socolovschi C, Labruna MB, Mediannikov O, Kernif T, et al. Update on tick-borne rickettsioses around the world: a geographic approach. Clin Microbiol Rev 2013; 26(4): 657-702. http://dx.doi.org/10.1128/CMR.00032-13. PMid:24092850.

Peckle M, Luz HR, Labruna MB, Serpa MC, Lima S, Maturano R, et al. Multi-locus phylogenetic analysis groups the New World bacterium Rickettsia sp. Strain ApPR with the Old World species R. africae; proposal of "Candidatus Rickettsia paranaensis". Ticks Tick Borne Dis 2019; 10(6): 101261. http://dx.doi.org/10.1016/j.ttbdis.2019.07.005. PMid:31337544.

Perez CA, Almeida AF, Almeida A, Carvalho VHB, Balestrin DC, Guimarães MS, et al. Carrapatos do gênero Amblyomma (Acari: Ixodidae) e suas relações com os hospedeiros em área endêmica para febre maculosa no Estado de São Paulo. Rev Bras Parasitol Vet 2008; 17(4): 210-217. http://dx.doi.org/10.1590/S1984-29612008000400008. PMid:19265580.

R Core Team. (2019). R: a language and environment for statistical computing [online]. Vienna: R Foundation for Statistical Computing; 2019 [cited 2020 Mar 5]. Available from: https://www.R-project.org/

Raoult D, Roux V. Rickettsioses as paradigms of new or emerging infectious diseases. Clin Microbiol Rev 1997; 10(4): 694-719. http://dx.doi.org/10.1128/CMR.10.4.694. PMid:9336669.

Sangioni LA, Horta MC, Vianna MC, Gennari SM, Soares RM, Galvão MAM, et al. Rickettsial infection in animals and Brazilian spotted fever endemicity. Emerg Infect Dis 2005; 11(2): 265-270. http://dx.doi.org/10.3201/eid1102.040656. PMid:15752445.

Saraiva DG, Fournier GFSR, Martins TF, Leal KPG, Vieira FN, Câmara EMVC, et al. Ticks (Acari: Ixodidae) associated with small terrestrial mammals in the state of Minas Gerais, southeastern Brazil. Exp Appl Acarol 2012; 58(2): 159-166. http://dx.doi. org/10.1007/s10493-012-9570-9. PMid:22585005.

Silveira I, Martins TF, Olegário MM, Peterka C, Guedes E, Ferreira F, et al. Rickettsial infection in animals, humans and ticks in Paulicéia, Brazil. Zoonoses Public Health 2015; 62(7): 525-533. http://dx.doi.org/10.1111/zph.12180. PMid:25643912.

Soares JF, Soares HS, Barbieri AM, Labruna MB. Experimental infection of the tick Amblyomma cajennense, Cayenne tick, with Rickettsia rickettsii, the agent of Rocky Mountain spotted fever. Med Vet Entomol 2012; 26(2): 139-151. http://dx.doi.org/10.1111/ j.1365-2915.2011.00982.x. PMid:22007869.

Souza CE, Camargo LB, Pinter A, Donalisio MR. High seroprevalence for Rickettsia rickettsii in equines suggests risk of human infection in silent areas for the Brazilian spotted fever. PLoS One 2016; 11(4): e0153303. http://dx.doi.org/10.1371/journal. pone.0153303. PMid:27064788.

Sponchiado J, Melo GL, Martins TF, Krawczak FS, Labruna MB, Cáceres NC. Association patterns of ticks (Acari: Ixodida: Ixodidae, Argasidae) of small mammals in Cerrado fragments, western Brazil. Exp Appl Acaro/ 2015; 65(3): 389-401. http://dx.doi.org/10.1007/ s10493-014-9877-9. PMid:25633262.

Stevenson M. epiR: tools for the Analysis of Epidemiological Data. R package version 1.0-11 [online]. 2020 [[cited 2020 June 30$].$ Available from: https://CRAN.R-project.org/package=epiR

Szabó MPJ, Pinter A, Labruna MB. Ecology, biology and distribution of spotted-fever tick vectors in Brazil. Front Cell Infect Microbiol 2013; 3: 27. http://dx.doi.org/10.3389/fcimb.2013.00027. PMid:23875178.

Teodoro AKM, Cutolo AA, Motoie G, Meira-Strejevitch CS, Pereira-Chioccola VL, Mendes TMF, et al. Gastrointestinal, skin and blood parasites in Didelphis spp. from urban and sylvatic areas in São Paulo state, Brazil. Vet Parasitol Reg Stud Rep 2019; 16: 100286. http://dx.doi.org/10.1016/j.vprsr.2019.100286. PMid:31027595.

Ueno TE, Costa FB, Moraes-Filho J, Agostinho WC, Fernandes WR, Labruna MB. Experimental infection of horses with Rickettsia rickettsii. Parasit Vectors 2016; 9(1): 499. http://dx.doi.org/10.1186/s13071-016-1784-y. PMid:27624315.

Weinert LA, Werren JH, Aebi A, Stone GN, Jiggins FM. Evolution and diversity of Rickettsia bacteria. BMC Bio/ 2009; 7(1): 6. http:// dx.doi.org/10.1186/1741-7007-7-6. PMid:19187530. 